\title{
Urbanization Processes in the Steppe Krai and Turkestan (late 19th - early 20th Centuries)
}

\section{Irina B. Bochkareva (a) \& Alexey A. Eremin (b)}

a) Altai State University. Barnaul, Russia. Email: portnygina[at]yandex.ru

b) Altai State University | The Altai Branch of Russian Academy of National Economy and Public Administration. Barnaul, Russia. Email: eremin.alexey[at]mail.ru

\begin{abstract}
At the beginning of the 20th century, the processes of urbanization were actively taking place in the Russian Empire, but in different regions they went with varying degrees of intensity. Modernization changes in the traditional agricultural and nomadic societies of the Central Asian region began after its final annexation to the Russian Empire, which happened quite late - in the 60-70s of the $19^{\text {th }}$ century. Based on the data of statistical surveys of the Steppe and Turkestan general-governorate's areas, the authors analyze the urban population's dynamics, the movement of its class and national composition in order to assess the level of urbanization of the region, as to what extent it reflects the general patterns of modernization and what is its regional specificity. The graphs compiled according to the Surveys show that in all nine areas of the region there was a quantitative increase in the urban population. The main incentives for urban growth were trade and railway construction. At the same time, another trend is observed: the proportion of citizens in the entire population does not increase significantly, but fluctuates in the range of several percentage points. The absence of pronounced dynamics of the urban population outpacing growth over the rural population indicates the initial stage of the Central Asia's urbanization. The low intensity of urbanization is quite corresponded to the Central Asian economic modernization imperial strategy, which consisted in the development of commodity specialization of agricultural sector for the needs of the metropolitan industry and peasant colonization of the region.
\end{abstract}

\section{Keywords}

Urbanization; Modernization; Russian Empire; Central Asia; Steppe Region; Turkestan; Regional Surveys; Statistics; Urban Population Movement; Urban Population Share

This work is licensed under a Creative Commons "Attribution” 4.0 International License 


\section{Урбанизационные процессы в Степном крае и Туркестане (конец XIX - начало XX вв.)}

\section{Бочкарева Ирина Борисовна (a), Еремин Алексей Алексеевич (b)}

a) Алтайский государственный университет. Барнаул, Россия. Email: portnygina[at]yandex.ru

b) Алтайский государственный университет | Алтайский филиал Российской Академии народного хозяйства и государственной службы при Президенте Российской Федерации. Барнаул, Россия. Email: eremin.alexey[at]mail.ru

\section{Аннотация}

В начале XX в. в Российской империи активно разворачивались процессы урбанизации, но, учитывая масштабы империи, в разных регионах они шли с разной степенью интенсивности. Модернизационые изменения традиционных земледельческого и кочевого обществ центральноазиатского региона начались после его окончательного присоединения к Российской империи, что произошло довольно поздно - в 60-70-е гг. XIX в. На основе данных Статистических обзоров областей Степного и Туркестанского генерал-губернаторств авторы анализируют динамику городского населения региона, подвижки его сословного и национального состава с целью оценить уровень урбанизации региона: насколько она отражает общие закономерности модернизации и в чем состоит ее региональная специфика. Графики, составленные по данным Обзоров, показывают, что во всех девяти областях региона шел количественный рост городского населения. Основными стимулами роста городов стали торговля и железнодорожное строительство. Города, которые становились железнодорожными узлами, показывали более высокие темпы прироста населения. В то же время наблюдается другая тенденция: удельный вес горожан во всем населении существенно не увеличивается, а колеблется в диапазоне нескольких процентных пунктов в большую или меньшую сторону. Отсутствие выраженной динамики опережающего роста городского населения над сельским говорит о начальной стадии урабанизационного процесса в регионе. Низкая интенсивность урбанизации вполне согласуется с имперской стратегией экономической модернизации Степного и Туркестанского края, которая заключалась в развитии товарной специализации отраслей сельского хозяйства для нужд промышленности метрополии и крестьянской колонизации региона.

\section{Ключевые слова}

урбанизация; модернизация; Российская империя; Центральная Азия; Степной край; Туркестан; обзоры областей; статистика; движение городского населения; доля городского населения

Это произведение доступно по лицензии Creative Commons “Attribution” («Атрибуция») 4.0 Всемирная 


\section{Введение}

Урбанизация является неотъемлемой составляющей системного процесса модернизации. Рост городов, городского населения, структура занятости важные индикаторы, демонстрирующие глубину модернизационного процесса и формирование индустриального общества в отдельно взятой стране и регионе. В начале XX в. Российская империя оставалась преимущественно аграрной страной, где сельское население, за исключением Привисленских губерний, составляло более $85 \%$. В то же время в империи активно разворачивались процессы урбанизации. К началу XX в. сложилась сеть крупных быстрорастущих городов, административных, индустриальных, торговых и транспортных центров с энергичными муниципальными учреждениями и значительными ресурсами для развития городского хозяйства (Миллер \& Черный, 2017, с. 5). Модернизационные изменения традиционного земледельческого и кочевого общества центральноазиатского региона начались после его окончательного присоединения к Российской империи, что произошло довольно поздно, в 60-70-е гг. XIX в. Анализ динамики движения городского населения Степного края и Туркестана, подвижки его сословного и национального состава позволяют проследить, насколько процесс урбанизации отражал общие закономерности модернизации и в чем состояла его региональная специфика. Историография изучения урабанизационного процесса в Российской империи в пореформенный период представлена преимущественно исследованиями городов европейской части России (Миллер \& Черный, 2017; Лаппо, 2001; Нефедова \& Трейвиш, 2001). Вместе с тем некоторые тенденции развития городов европейской части были актуальны и для азиатской части России, как показало наше исследование. Интересные выводы по социальноэкономическому развитию городов Степенного края представлены в исследовании Р. Джаниевой (2007).

Основную источниковую базу исследования составили данные ежегодных статистических обзоров областей Степного и Туркестанского генерал-губернаторств за 1880-1915 гг. (Обзор Акмолинской, 1871-1917; Обзор Закаспийской, 1892-1916; Обзор Самаркандской, 1891-1912; Обзор Семипалатинской, 1871-1913; Обзор Семиреченской, 1883-1915; Обзор Сыр-Дарьинской, 1890-1916; Обзор Тургайской, 1871-1916; Обзор Уральской, 1868-1916; Обзор Ферганской, 1889-1916). В силу комплексного характера содержащихся в обзорах сведений исследователи обращаются к этим документам для изучения самых разных сторон общественной жизни в России соответствующего периода. Обзоры рассматриваются в качестве важного источника сведений по истории развития образования (Рыгалова, 2021), медико-санитарной (Власова, 2020) и ветеринарной (Алешин, 2019) служб, промышленности (Макушев, 2020), преступности (Харсеева, 2017), кредитно-банковской системы (Еремин, 2021) и др. В статье мы остановимся на анализе показателей численности городского населения 
в абсолютном и относительном выражении, а также распределении городского населения по сословиям и в ряде случаев по национальным группам. Территориальные рамки исследования - Степной и Туркестанский край в составе девяти областей, сложившихся к концу XIX в. Степной край: Акмолинская, Семипалатинская, Тургайская и Уральская области. Туркестанский край: Семиреченская, Сыр-Дарьинская, Ферганская, Самаркандская и Закаспийская области.

\section{Методология и методы}

Методологической основой исследования стала теория модернизации как комплексное междисциплинарное направление, изучающее закономерности развития современного общества. Одним из положений теории модернизации являются так называемые количественные индикаторы оценки первичной модернизации соответствующей стадии индустриального общества, предложенные профессором А. Инкелесом (Хэ Чуанци, 2011, с. 60). В число 10 базовых индикаторов модернизации входит доля городского населения во всем населении в целом, составляющая >50\%, если общество завершило первичную модернизацию. Этот индикатор в числе других учитывался нами как стандарт для оценки уровня урбанизации центральноазиатского региона в имперский период.

Фактологической информационной базой для исследования выступил комплекс обзоров областей центральноазиатских окраин Российской империи, из которых извлекались все статистические данные, характеризующие города и городское население изучаемой территории. На основе этих материалов была создана база данных в формате электронных таблиц Microsoft Excel, включавшая (в случае наличия в первоисточнике) следующие показатели относительно городов: численность населения обоего пола, численность мужчин и женщин, сословный состав населения, национальный состав населения. Отметим, что последний показатель встречается в обзорах крайне редко.

Для получения данных о городском населении областей в целом показатели по отдельным городам каждой области суммировались; в некоторых случаях такие обобщенные показатели уже были представлены в самих обзорах. Кроме того, для расчета ряда относительных показателей (удельного веса) в базу данных были собраны сведения об общей численности населения областей. Применение математико-статистических методов позволило дополнить первичные сведения расчетными, в базу данных были внесены такие показатели, как доля городского населения, доли мужчин и женщин во всем населении городов, абсолютный прирост и темпы прироста городского населения, доли лиц отдельных сословий в населении городов, доли лиц отдельных национальностей в населении городов.

Следующим этапом работы стала визуализация основных показателей из базы данных, позволившая выявить и наглядно представить особенности дина- 
мики и состояния городского населения изучаемой территории. Для каждого города был построен линейный график динамики численности его населения, для городского населения областей были созданы круговые диаграммы сословного и национального состава на некоторые даты. Наиболее показательные из них представлены в статье.

Таким образом, основным инструментом в работе с количественными с данными послужили методы описательной статистики.

\section{Результаты}

Хотя ежегодные статистические обзоры областей Степного и Туркестанского генерал-губернаторств страдают пробелами данных по отдельным показателям населения за отдельные годы, что не даёт возможности выстроить последовательный, непрерывный статистический ряд, тем не менее построенные графики динамики численности городского населения четко показывают его количественный рост во всех областях изучаемого региона (см. Рисунки 1 и 2). При этом лидерами по приросту городского населения являются Ферганская, Сыр-Дарьинская и Акмолинская области, которые в большей степени, чем остальные, были интегрированы в начале XX в. в общероссийский рынок. Количественная разница в городском населении почти в 10 раз на конец изучаемого периода между самым низким показателем в Тургайской области и самым высоким в Ферганской области не случайна и обусловлена историческими факторами градообразования и готовностью городов реагировать на вызовы модернизации.

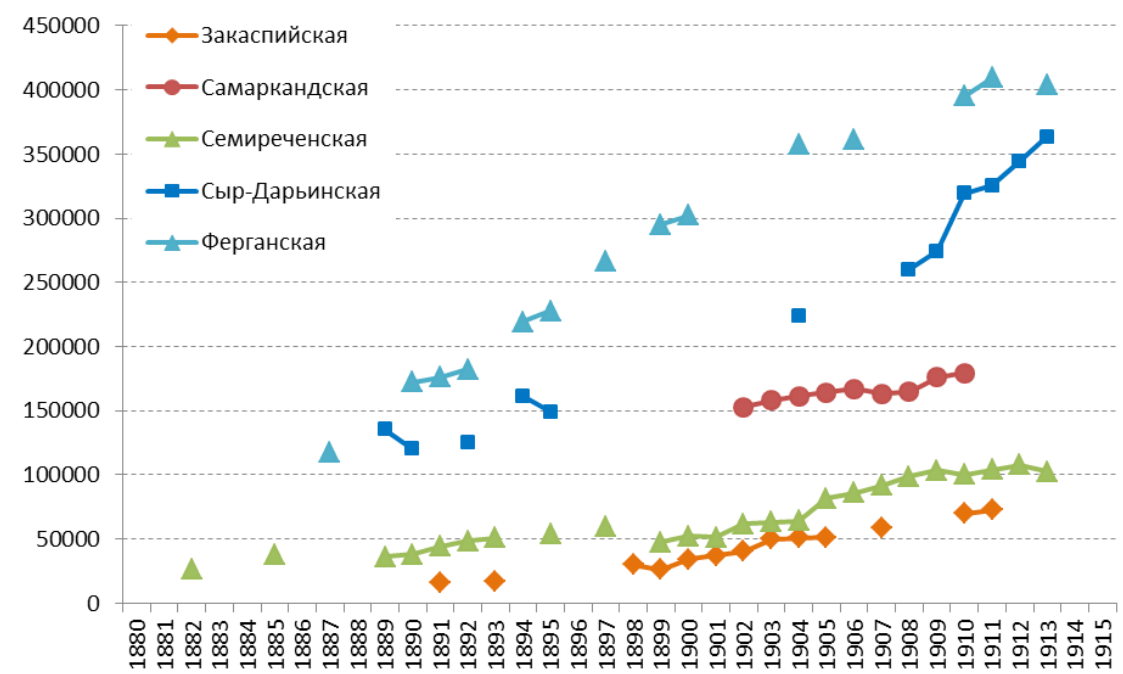

Рисунок 1. Динамика численности городского населения областей Степного края Российской империи в 1880-1915 гг., человек, на конец года

Figure 1. Dynamics of the urban population of the regions of the Steppe Krai of the Russian Empire in 1880-1915, number of people, at the end of the year 


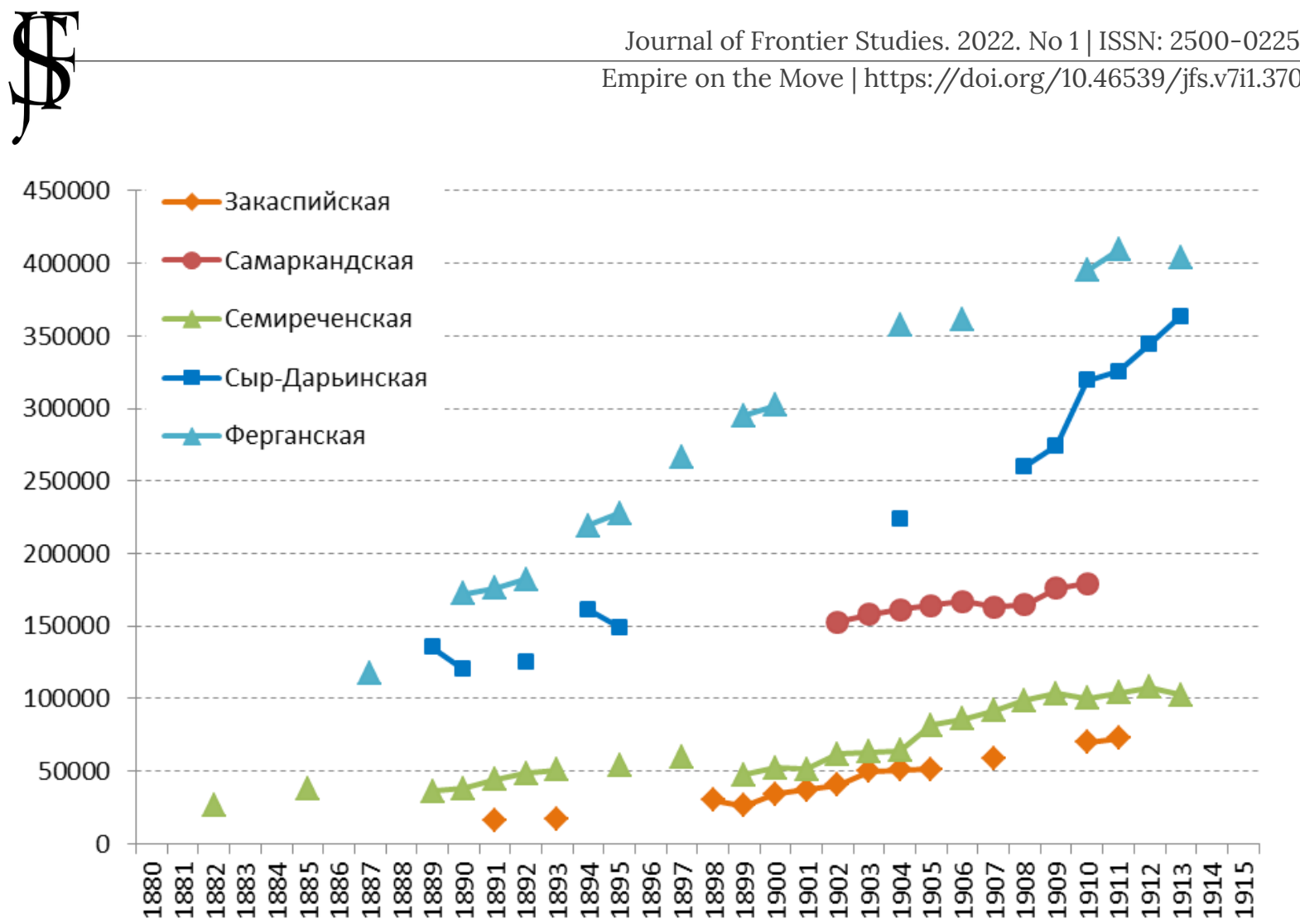

Рисунок 2. Динамика численности городского населения областей Туркестана Российской империи в 1880-1915 гг., человек, на конец года

Figure 2. Dynamics of the urban population of the regions of Turkestan of the Russian Empire in 1880-1915, number of people, at the end of the year

В процессе модернизации драйвером роста городов становится их роль в развитии рыночных, товарно-денежных отношений, превращение городов из военных и административных в индустриальные и торговые центры, связанные с другими регионами современными коммуникациями. Во второй половине XIX в. в России именно индустрия и железнодорожный транспорт становятся реальными факторами градообразования и развития уже имеющихся городов (Лаппо, 2001, с. 72). В этом отношении города Степного края и Туркестана имели разные стартовые позиции, вступая в эпоху модернизации. Исторически основные областные и уездные городские центры Степного края: Семипалатинск, Усть-Каменогорск, Павлодар, Актюбинск, Акмолинск, Тургай и другие, - возникли как военные форпосты, крепости в процессе продвижения Российской империи в регион в XVIII - первой половине XIX в. и в этом отношении воплощали характерную для России практику градообразования. Позже они получали статус областных или уездных административных центров. Как следствие, в национальном составе городов Степного края абсолютно доминировало русское население, хотя все города по составу были многонациональными. В отличие от Степного края, в Туркестане к моменту его присоединения к Российской империи уже существовали города с многовековой историей, культурой градостроительства и организации городской 
жизни: Самарканд, Ташкент, Коканд и другие. Фактором длительного существования и развития этих городов являлся не столько их административный статус в многочисленных государственных образованиях, приходивших на смену друг другу в Туркестане, сколько роль в региональной и даже международной торговле. Показательно, что удельный вес городских жителей в Средней Азии ${ }^{1}(12,1 \%)$ по итогам переписи населения 1897 г. был практически таким же, как в Европейской России (12,9\%), и плотность населения возрастала именно в юго-восточных областях региона (Фортунатов, 1906, с. 5). Став частью Российской империи, города Туркестана в массе своей не утратили роли экономических центров, а, наоборот, получили дополнительные стимулы для развития в условиях формирования общероссийского рынка. Поскольку основной экономический интерес метрополии в регионе состоял в возможности вывоза аграрно-сырьевых ресурсов, прежде всего, хлопка из земледельческих оазисов Туркестана для нужд российской промышленности, постольку планирование железнодорожных коммуникаций происходило с тем расчётом, чтобы подвести их к уже сложившимся торговым центрам региона (Бочкарева, 2020). Степной край рассматривался в связи с этим как транзитное пространство, и каким-то его военно-административным городским центрам «повезло» стать и железнодорожными станциями, а каким-то нет.

Так, ряд городов Степного и Туркестанского края, таких как Петропавловск, Актюбинск, Ташкент, Андижан, показали значительный, даже местами скачкообразный, прирост населения после строительства Среднеазиатской, Сибирской и Ташкентской железных дорог (см. Рисунок 3).

Строительство железных дорог в центральноазиатском регионе послужило мощным стимулом развития товарности и специализации сельского хозяйства, продукция которого была востребована на общероссийском рынке. Города региона, превратившиеся в железнодорожные узлы и обеспечивающие транзитную торговлю, стали, таким образом, «точками роста», пространством более выгодного приложения таких факторов производства, как труд и капитал. Показательна в этом отношении картина динамики населения Ташкента. После открытия Ташкентской железной дороги в 1906 г. город вернул себе роль регионального центра транзитной торговли между Туркестаном и европейской частью России, которую он играл в период караванной торговли. В результате за период 1908-1913 гг. население Ташкента выросло в целом на 65 тыс. человек или на 34\%. Среднегодовой темп прироста населения за этот период составил около 6\%. На 1 января 1914 г. Ташкент входил в число пяти городов Российской империи, за исключением

1 В регион «Средняя Азия» в материалах Переписи включается территория Степного и Туркестанского генерал-губернаторств. В статье мы используем название Центральная Азия, утвердившееся применительно к этому региону после распада СССР. 
Санкт-Петербурга и Москвы, с населением более 250 тыс. человек ${ }^{2}$ (Статистический ежегодник России, 1915, с. 135-136).

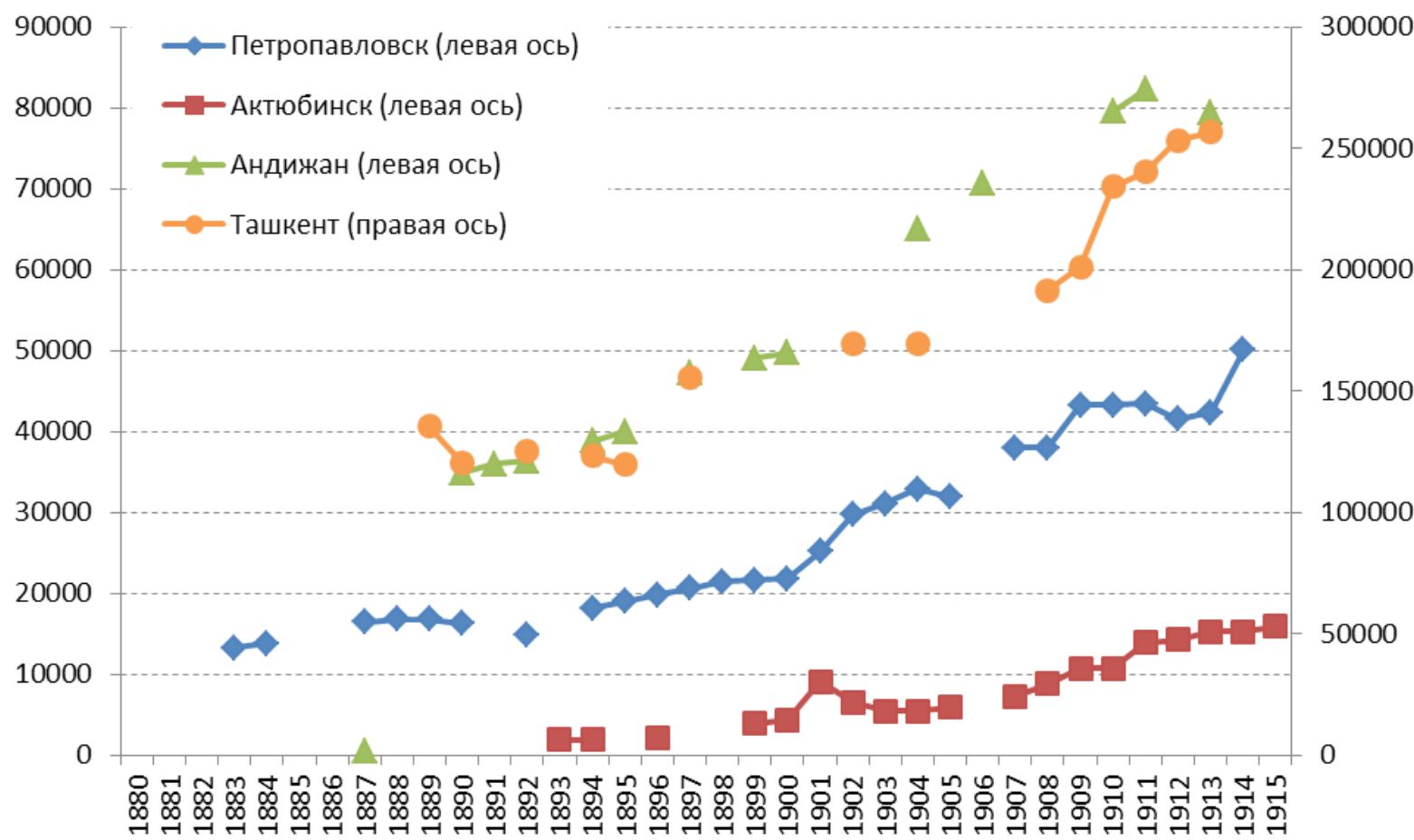

Рисунок 3. Динамика численности населения Актюбинска, Андижана, Петропавловска и Ташкента в 1880-1915 гг., человек, на конец года

Figure 3. Population dynamics of Aktyubinsk, Andijan, Petropavlovsk and Tashkent in 1880-1915, number of people, at the end of the year

В Степном крае, пожалуй, самым ярким примером зависимости роста населения от появления железнодорожных коммуникаций является Петропавловск. Население Петропавловска за период 1887-1900 гг. увеличилось с 16 до 22 тыс. человек, среднегодовой темп прироста за этот период составил 2\%. В период с 1900 по 1914 гг., когда в городе полноценно начинает функционировать станция Сибирской железной дороги, рост населения заметно ускоряется. Число жителей увеличилось до 50 тыс., или на 130\%, среднегодовой тем прироста за эти годы превысил 6\%. Из заурядного уездного города Петропавловск начинает превращаться в основной центр стационарной торговли восточных областей Степного края, потеснив в этом отношении Акмолинск, являвшийся центром ярмарочной торговли в регионе. Накануне первой мировой войны в Петропавловске оборот стационарных торговых заведений

2 Города Российской империи, численность населения которых в 1914 г. превышала 250 тыс. чел, но была меньше 1 млн. - Киев, Варшава, Рига, Тифлис, Ташкент. 
составлял более 9 млн. руб., а в Акмолинске - около 1 млн. руб. (Обзор Акмолинской области...[по годам], 1914, с. 37).

Вместе с тем ряд городов с менее выгодным географическим положением, расположенных вдали от сложившейся системы железнодорожных коммуникаций и торговых путей, оказались в начале XX в. в состоянии «застоя». Численность их населения либо не росла, либо вообще сокращалась (см. Рисунок 4). В число последних попали небольшие уездные города, например, Тургай и Иргиз Тургайской области, Ура-Тюбе, Ката-Курган Самаркандской области. Тургай и Иргиз в современном Казахстане утратили статус городов и являются селами.

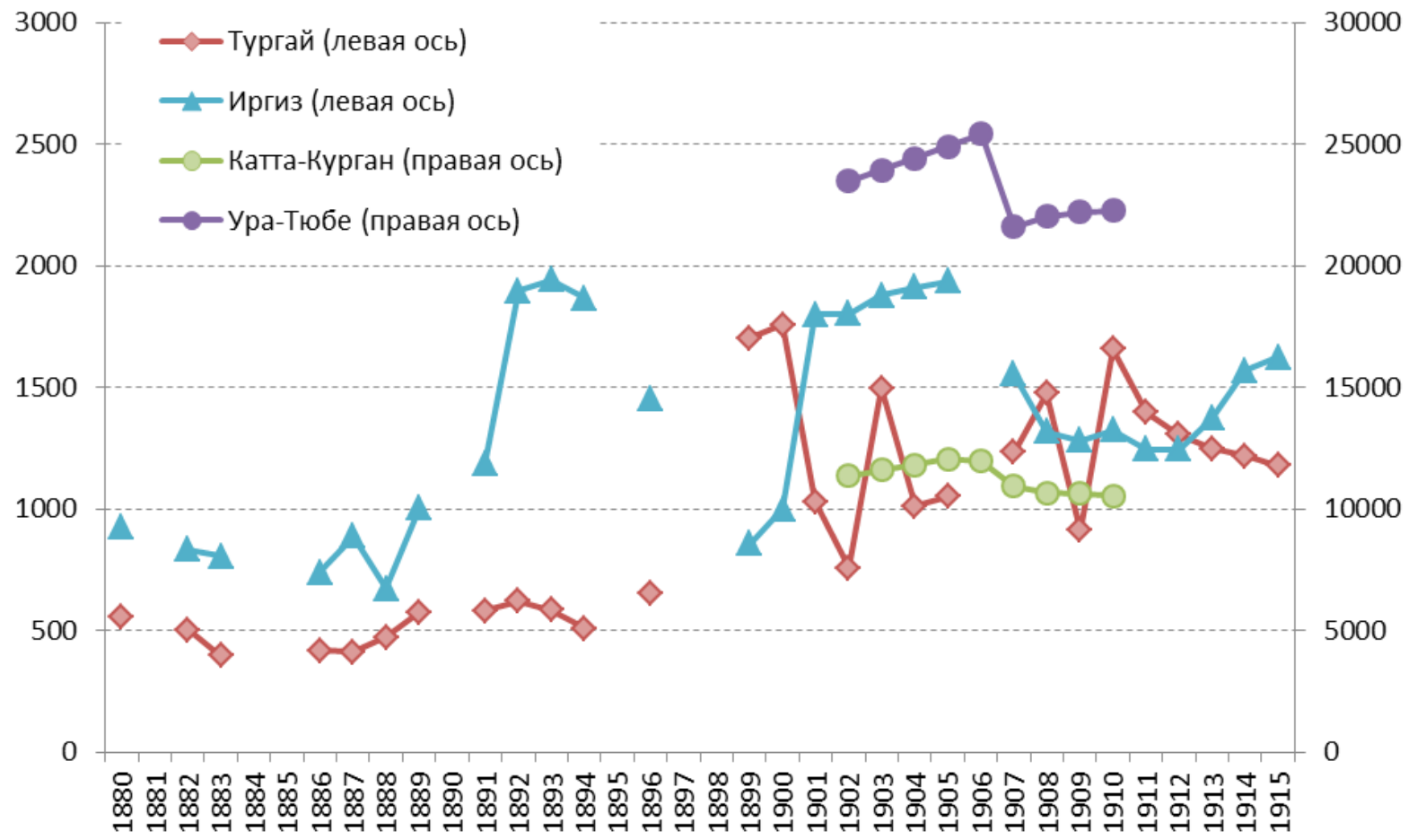

Рисунок 4. Динамика численности населения Тургая, Иргиза, Катта-Кургана и Ура-Тюбе в 1880-1915 гг., человек, на конец года

Figure 4. Population dynamics of Turgai, Irgiz, Katta-Kurgan and Ura-Tyube in 1880-1915, number of people, at the end of the year

Системным сдвигам в процессе урбанизации отвечало и то, что тенденция к росту численности жителей крупных городов Степного и Туркестанского края на протяжении изучаемого периода происходила преимущественно механическим путем, за счет оседания сельского населения в городах. Так, население Петропавловска с 1897 по 1914 гг. выросло на 30 тысяч человек, при этом его естественный прирост в эти годы колебался от 300 до 500 человек в год и лишь в 1914 г. он составил 1492 человек. В Акмолинске соот- 
ветственно за те же годы население увеличилось на 9052 человек, а естественный прирост составлял в среднем около 150-250 человек в год и лишь в 1907 г. превысил 500 человек. Таким образом, на долю естественного прироста в этих городах приходилось примерно от 20 до 30\% увеличения численности местного населения (Буктугутова, 2010, с. 9). Особенностью урбанизационного процесса являлось то, что механический прирост городского населения обеспечивался не столько путем переселения коренного сельского населения в города, сколько в результате широкого крестьянского переселенческого движения в Степной и Туркестанский край из европейской части России. Значительная часть обедневших крестьян, не сумев адаптироваться к новым условия проживания, вынуждена была уходить на заработки в города, содействуя росту их населения и изменению социального облика городских поселений. Одним из сценариев вынужденного оседания крестьян в городах, характерным для Туркестанского края, было неорганизованное, стихийное переселение русских крестьян, для которых местной администрацией не были выделены заранее земли для заселения.

Основная закономерность динамики сословной структуры городского населения всех областей региона - это рост удельного веса крестьян. В Акмолинской области, которая приняла 56\% от общего числа переселенцев в Степной край, доля крестьян в составе городского населения выросла с 14\% в 1890 г. до 36\% в 1914 г. (см. Рисунок 5). Близкие в процентном отношении показатели демонстрирует Тургайская область; в остальных областях удельный вес крестьян в составе городского населения был меньше. Так, в Сырдарьинской области на 1914 г. он составил 14\%, но учитывая, что Ташкент был самым многонаселенным городом региона и в 1,5 раза превосходил Омск, в абсолютном выражении численность крестьян была не меньше, чем в городах Акмолинской области. В контексте анализа процесса урбанизации увеличение доля крестьянства в сословной структуре городов представляет интерес, поскольку именно крестьянство составляло социальную базу формирования рынка свободной рабочей силы и пролетариата в городах в процессе промышленного переворота и индустриализации.

Вторая сословная группа, которая на рубеже XIX-XX в. показала рост удельного веса в составе городского населения, хотя не столь последовательный, как крестьянство, - это мещане. Мещане являлись самой большой по численности сословной группой в городах Российской империи. В изучаемый период самый высокий удельный вес мещанства в населении городов региона был в Семипалатинской области - 50\%. В Сырдарьинской области мещане составляли 8\% городского населения, но это была самая многочисленная сословная группа среди русскоязычного населения городов, в которых 80\% составляло местное коренное население. Изначально на момент возникновения по Жалованной грамоте городам 1785 г. мещанство понималось как низшее торговое сословие, объединяющее мелких торговцев и предпринима- 
телей. В пореформенный период это сословие городских обывателей включало людей довольно разных профессий, от мелких торговцев, служащих, интеллигенции, до наемных рабочих.

1890
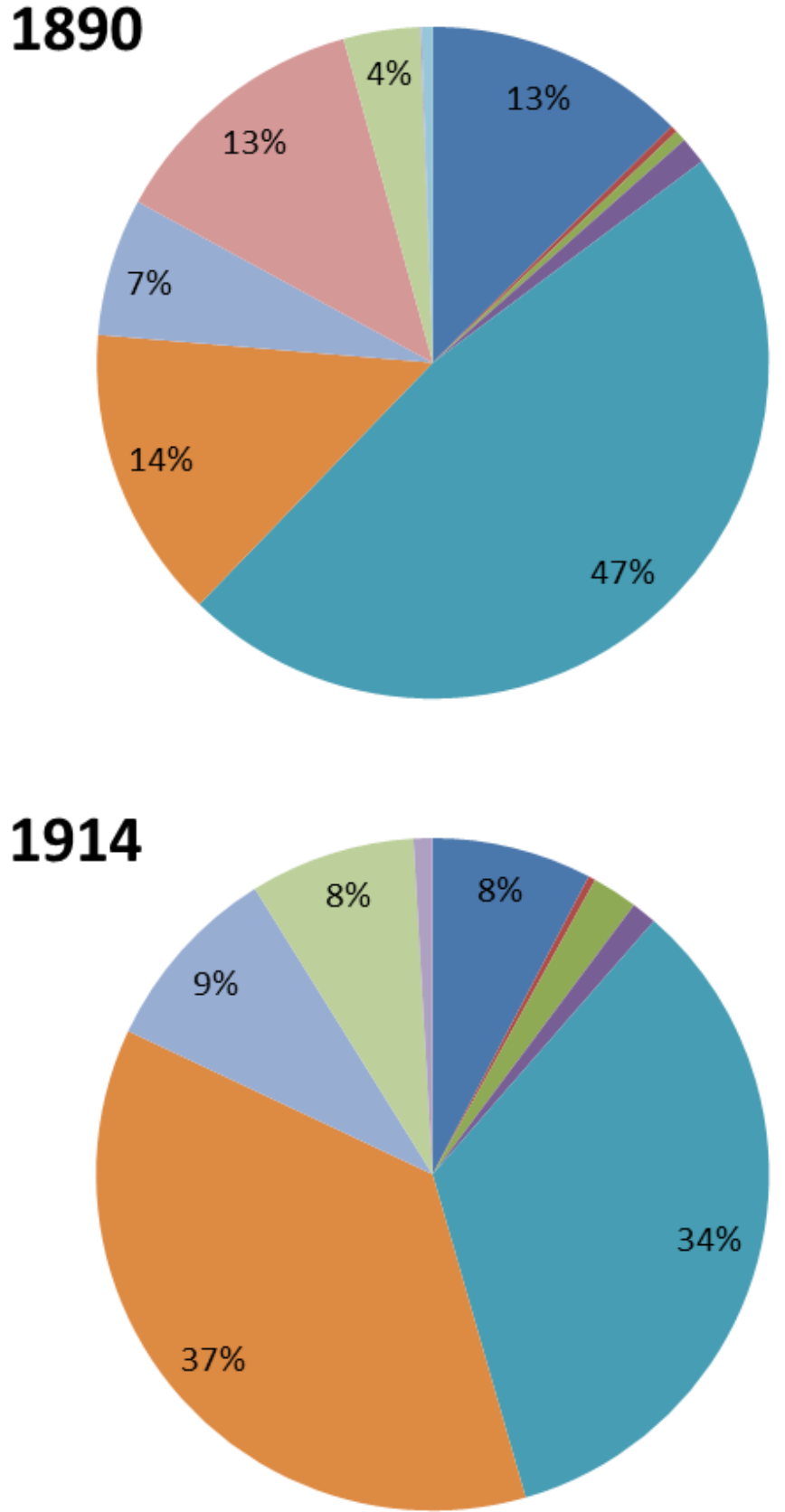

- Дворяне

口 Духовенство

п Почетные граждане

п Купцы

Мещане

Крестьяне

- Казаки

- Военные сословия

Инородцы

Иностранные подданные

- Прочие
口 Дворяне

口 Духовенство

п Почетные граждане

- Купцы

мещане

- Крестьяне

- Казаки

Военные сословия

Инородцы

Иностранные подданные

Прочие

Рисунок 5. Динамика сословного состава населения Акмолинской области, $\%$, на конец года

Figure 5. Dynamics of the estate composition of the Akmola region population, $\%$, at the end of the year 
Сословно-национальная структура городов Семипалатинской области показывает значительную долю в составе населения киргизов, они составляли вторую по численности после мещан группу населения (24\% в 1911 г.). Обедневшие кочевники-киргизы являлись источником пополнения рынка рабочей силы для мануфактур и фабрик. В то же время данные Обзоров не дают возможности четко проследить национальный состав коренного населения городов и его подвижки, поскольку разные национальные группы коренного населения объединялись в статистике отдельных областей либо в группу «инородцы», либо «туземцы», либо «городские обыватели-туземцы». В Обзорах Семиреченской области в составе городского населения выделялась группа «Сельские обыватели», куда включались как русские крестьяне, так и представители коренного населения (Обзор Семиреченской области ... [по годам], 1905).

Следует отметить, что сословность как критерий учета населения в статистических обзорах по Степному и Туркестанскому краю не отражает процесс формирования, удельный вес и национальную принадлежность новых социальных групп: пролетариата и промышленной буржуазии. Поскольку объективно модернизационные изменения в экономической и социальной структуре городов Степного края и Туркестана происходили, мы согласны в выводом Джаниевой P.М., что «сословное положение в начале XX в. уже зачастую не соответствовало профессиональным занятиям горожан, поскольку те же мещане и крестьяне, как правило, были заняты в сфере торговли и промышленности, либо в качестве предпринимателей, а большей частью как лица наемного труда» (2007, с. 25). Вместе с тем промышленность была представлена преимущественно кустарными и мануфактурными предприятиями по переработке аграрного сырья, отчасти имевшими сезонный характер; фабричные предприятия стали возникать в регионе только в начале XX в. Поэтому складывание пролетариата, как отдельной социальной группы, представители которой не идентифицируют себя как крестьяне или мещане, находилось на начальной стадии. В 1900 г. число рабочих на предприятиях Степного края составляло всего 8221 человек (Россия, 1903, с. 286). Согласно данным переписи населения 1897 г., в Ферганской области только 253 человека были заняты на фабричных предприятиях по обработке хлопка и производству изделий из него (и это самый высокий показатель по региону), 789 человек были заняты в кустарном производстве этой отрасли. (Численность и состав рабочих, 1906, с. 13). Для сравнения, в Московской губернии это 99 тыс. 930 чел, во Владимирской - 75 тыс. 721 (Численность и состав рабочих, 1906, с. 11). Появление промышленности закономерно вносило изменения в социальный и профессиональный состав населения городов региона, но индустрия в пореформенный период еще не стала определяющим стимулом роста городов. Большинство промышленных предприятий были привязаны к местам добычи минеральных ресурсов либо возникали в сельской местности. Кроме того, 
отводя Степному краю и Туркестану роль агарной окраины империи и отчасти из военно-стратегических соображений, государство сознательно сдерживало развитие промышленного сектора в регионе. Положение об управлении Туркестанским краем 1886 г. запрещало приобретать недвижимость в Туркестане иностранным подданным и всем нехристианам, за исключением лиц местного населения и «сопредельных стран» - имелись в виду Бухара и Хива (ст. 262) (Положение об управлении, 1903). Возможность приобретения недвижимости для юридических лиц и различного рода товариществ была ограничена законом 1894 г., ст. 15 которого предоставляла данное право товариществам и акционерным обществам, состоявшим исключительно из русских подданных и нехристиан местного происхождения. Только в 1897 г. акционерным обществам Туркестана было разрешено выпускать акции на предъявителя, что открывало возможность для иностранного капитала, но для этого требовалось разрешение верховной власти (Лысенко, 2019, с. 45).

Вместе с тем индикатором модернизации является не просто количественный рост городского населения, а увеличение его удельного веса относительно сельского. По этому индикатору всех областях региона наблюдается общая тенденция: доля горожан от общего числа жителей существенно не увеличивается, а колеблется на уровне нескольких процентных пунктов в большую или меньшую сторону. Интересно, что такая же картина наблюдалась и в европейской части России в XVIII - первой половине XIX в.; тенденция к росту удельного веса городского населения обозначилась только со второй половины XIX в. после отмены крепостного права (Миронов, 2003, с. 315). Самая высокая доля городского населения - 19\% к началу Первой мировой войны, - была в Ферганской области. При этом на графике видно, что удельный вес городского населения за период с 1892 г. в 1913 г. даже сократился на 2,2 п.п. при росте в абсолютном выражении в 3,5 раза (см. Рисунок 6). Такой же относительно высокий уровень показателя урбанизированности наблюдался в 1909-1910 гг. в Самаркандской области - около 19\%, следом шли Сыр-Дарьинская - около 17\% и Закаспийская - около 15\%. Самая низкая доля городского населения с тенденцией к уменьшению была в Тургайской области - 5\% в 1915 г. Меньше 10\% населения жили в городах Семиреченской, Семипалатинской и Уральской областей (см. Таблица 1). 
$\$$

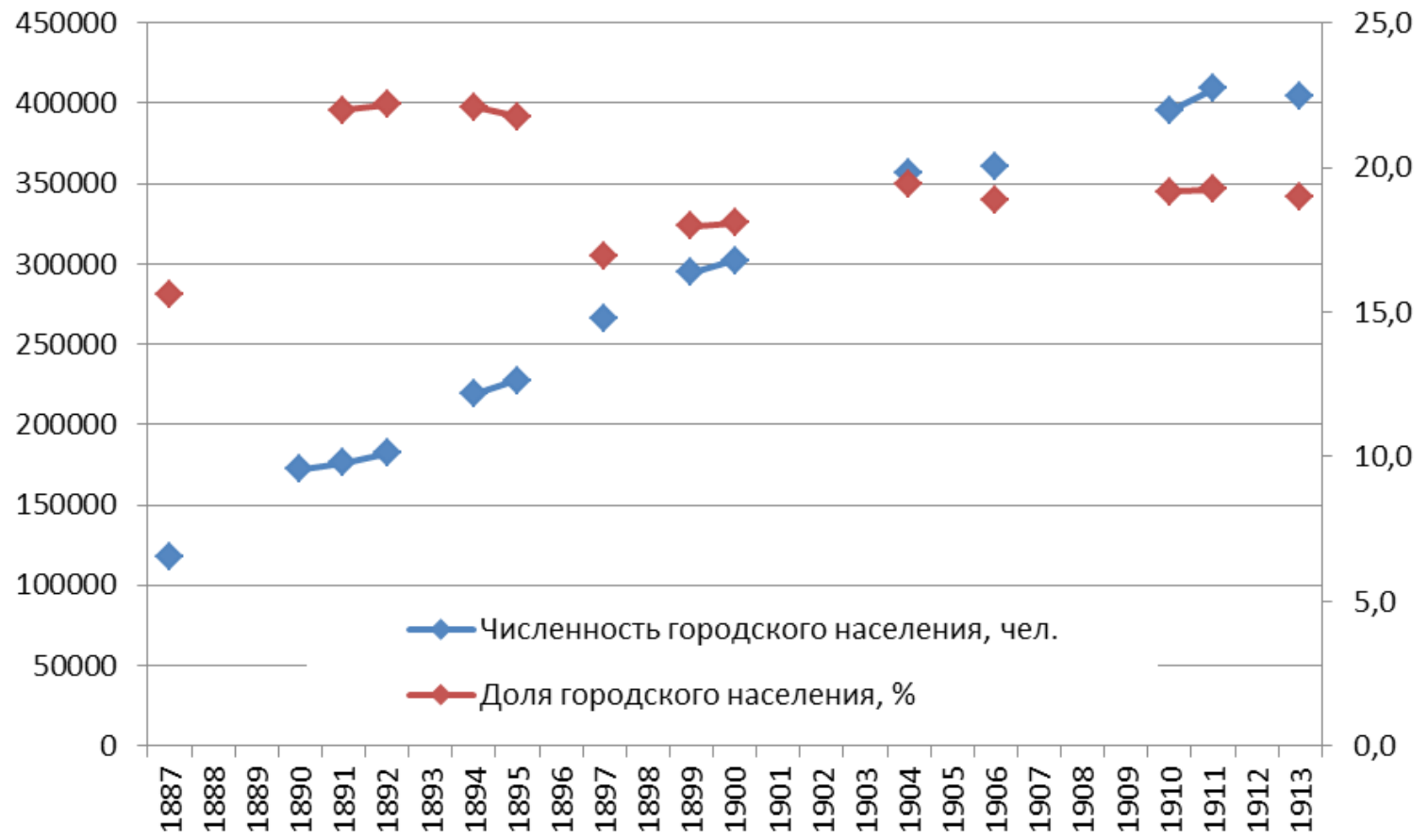

Рисунок 6. Доля городского населения в Ферганской области Туркестанского края в 1887-1913 гг., \%, на конец года

Figure 6. The share of the urban population in the Fergana region of the Turkestan in 1887$1913, \%$, at the end of the year

Мы полагаем, что отсутствие выраженного роста удельного веса городского населения в центральноазиатском регионе Российской империи связано с процессом интенсивной крестьянской колонизации его территории. Спрос на аграрное сырье на российском и международном рынке также делал сельское хозяйство более прибыльной сферой, чем торгово-промышленная деятельность, что сдерживало отток населения в города. 


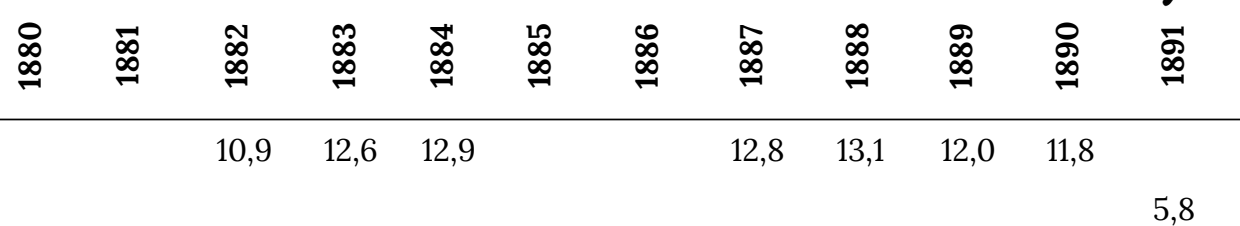

Закаспийская

Самаркандская

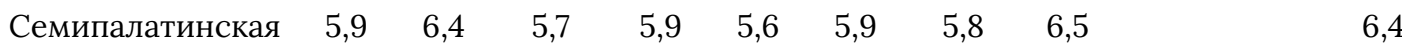

Семиреченская

4,2

5,7

$5,4 \quad 5,6$

6,5

Сыр-Дарьинская

$11,8 \quad 10,4$

Тургайская

$0,5 \quad 0,4 \quad 0,4$

$0,3 \quad 0,4 \quad 0,3 \quad 0,4$

Уральская

$6,1 \quad 5,9 \quad 5,8 \quad 6,5$

$7,9 \quad 7,7$

Ферганская

15,6

$\begin{array}{llll}7,7 & 7,3 & 7,2 & 7,2\end{array}$

\begin{tabular}{|c|c|c|c|c|c|c|c|c|c|c|c|c|}
\hline & $\stackrel{\text { \& }}{\stackrel{\infty}{\sim}}$ & $\stackrel{\mathscr{\infty}}{\stackrel{\infty}{\sim}}$ & $\underset{\mathscr{D}}{\stackrel{\infty}{*}}$ & 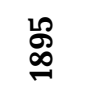 & $\stackrel{\mathscr{\infty}}{\mathscr{\infty}}$ & $\underset{\mathscr{\infty}}{\stackrel{0}{\sim}}$ & $\stackrel{\infty}{\stackrel{\infty}{\infty}}$ & $\underset{\mathscr{\infty}}{\stackrel{\infty}{=}}$ & $\stackrel{8}{\circ}$ & ஓ্ & ๙ิ & $\stackrel{\mathscr{\vartheta}}{\stackrel{9}{\sigma}}$ \\
\hline Акмолинская & 13,7 & 13,6 & 13,5 & 13,4 & 12,6 & 12,3 & 12,2 & 12,0 & 11,6 & 11,2 & 11,9 & 12,2 \\
\hline Закаспийская & & 5,0 & & & & & 8,1 & 7,3 & 9,3 & 10,0 & 10,4 & 12,4 \\
\hline Самаркандская & & & & & & & & & & & 15,8 & 16,0 \\
\hline Семипалатинская & & & & & & 6,8 & 6,8 & 6,8 & 6,9 & 6,9 & 7,0 & 7,5 \\
\hline Семиреченская & 7,0 & 7,1 & & 7,0 & & 6,8 & & 5,1 & 5,4 & 5,2 & 6,0 & 6,0 \\
\hline Сыр-Дарьинская & 10,2 & & 13,3 & 12,2 & & & & & & & & \\
\hline Тургайская & 0,7 & 4,7 & 5,3 & & 4,7 & & & 5,2 & 5,0 & 6,1 & 6,1 & 5,7 \\
\hline Уральская & 7,4 & 7,3 & 7,4 & & & 8,8 & 8,8 & 8,7 & 8,7 & 8,8 & 8,7 & 8,8 \\
\hline \multirow[t]{2}{*}{ Ферганская } & 22,2 & & 22,1 & 21,8 & & 17,0 & & 18,0 & 18,1 & & & \\
\hline & 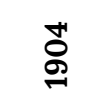 & 녕 & ஓ & $\stackrel{\hat{\circ}}{\stackrel{9}{\sigma}}$ & $\stackrel{\infty}{\stackrel{9}{9}}$ & $\stackrel{9}{9}$ & 응 & s & ฮี & $\frac{m}{g}$ & $\stackrel{\leftrightarrows}{\stackrel{9}{\leftrightarrows}}$ & $\stackrel{\text { 옴 }}{9}$ \\
\hline Акмолинская & 12,4 & 12,5 & & 14,4 & 13,1 & 12,6 & 13,3 & 13,4 & 13,3 & 13,4 & 14,0 & \\
\hline Закаспийская & 12,5 & 14,5 & & 16,3 & & & 15,0 & 15,1 & & & & \\
\hline Самаркандская & 16,0 & 16,0 & 16,0 & 18,6 & 18,1 & 19,0 & 18,7 & & & & & \\
\hline Семипалатинская & 7,6 & & 6,9 & 7,3 & 7,4 & 7,3 & 7,6 & 8,3 & & & & \\
\hline Семиреченская & 5,9 & 7,5 & 8,0 & 8,6 & 8,8 & 8,8 & 8,2 & 8,3 & 8,4 & 7,7 & & \\
\hline Сыр-Дарьинская & 14,1 & & & & 15,1 & 15,3 & 16,7 & 16,3 & 16,8 & 17,3 & & \\
\hline Тургайская & 5,4 & 5,3 & & 5,4 & 5,5 & 5,3 & 5,5 & 5,8 & 5,6 & 5,2 & 4,8 & 5,0 \\
\hline Уральская & 8,9 & 9,0 & 9,2 & 9,3 & 9,4 & 9,2 & 9,0 & 9,0 & & 8,9 & 8,6 & 8,8 \\
\hline Ферганская & 19,4 & & 18,9 & & & & 19,2 & 19,2 & & 19,0 & & \\
\hline
\end{tabular}

Таблица 1. Доля городского населения в областях центральноазиатских окраин Российской империи в 1880-1915 гг., \%, на конец года

Table 1. The share of the urban population in the regions of the Central Asian outskirts of the Russian Empire in 1880-1915, \%, at the end of the year 
Journal of Frontier Studies. 2022. No 1 | ISSN: 2500-0225

Empire on the Move | https://doi.org/10.46539/jfs.v7i1.370

\section{Выводы}

Рост численности городского населения во всех областях Степного края и Туркестана, подтвержденный анализом статистических данных Обзоров областей, наряду с ростом товарности хозяйства, появлением промышленных предприятий и современного транспорта в регионе свидетельствует, что традиционное центральноазиатское общество постепенно начинало подключаться к универсальному по своей сути процессу модернизации. Вместе с тем по такому базовому индикатору модернизации как доля городского населения во всем населении региона мы наблюдаем отсутствие выраженной динамики опережающего роста городского населения над сельским, характерное для индустриального общества, что говорит о начальной стадии урабанизационного процесса и отражает его региональную специфику. Низкая интенсивность урбанизации вполне согласуется с имперской стратегией экономической модернизации Степного и Туркестанского края, которая заключалась в развитии товарной специализации отраслей сельского хозяйства для нужд промышленности метрополии и крестьянской колонизацией региона, порой в ущерб развитию предприятий фабричного сектора. В свете этого не индустрия, а железные дороги, которые были построены государством в Центральной Азии и Сибири в первую очередь из стратегических, а потом уже экономических мотивов, стали тем экономическим фактором, который оказал значительное влияние на динамику роста и структуру населения городов. Таким образом, города региона отражали объективные системные тренды, запущенные процессом модернизации и характерные для Российской империи в целом, но в изучаемый период еще не превратились в полюса роста, где обеспечивалось экономически более выгодное приложение факторов производства - труда и капитала.

\section{Благодарности}

Исследование выполнено за счет гранта Российского научного фонда (проект № 19-18-00180).

\section{Список литературы}

Алешин, П. Н. (2019). Функционирование земской ветеринарной службы в России во второй половине XIX - начале XX века (по обзорам губерний). Современная научная мысль, $5,54-61$.

Бочкарева, И. Б. (2020). Частный капитал в процессе железнодорожного строительства в Туркестане (70-е гг. XIX - начало XX в.). Известия Алтайского государственного университета, 5, 13-18. https://doi.org/10.14258/izvasu(2020)5-01

Буктугутова, Р. С. (2010). Из истории повседневности жителей уездных городов Степного края в конце XIX - начале XX века. Вестник Казахского национального педагогического 
университета илени Абая. Серия «Исторические и сощиально-политические науки», $2,8-13$.

Власова, А. И. (2020). Характеристика медико-санитарной службы Акмолинской области Степного края в 70-е гг. XIX в. -Начале XX в. (По статистическим обзорам области за 18701915 гг.). Известия Алтайского государственного университета, 3, 25-30. https://doi.org/10.14258/izvasu(2020)3-03

Джаниева, Р. М. (2007). Социально-экономическое и культурное развитие уездных городов Степного края конеи XIX - начало XX вв. [Автореферат дис. ... кандидата исторических наук]. Омский государственный педагогический университет.

Еремин, А. А. (2021). Обзоры областей как источник по кредитно-банковской системе в Степном крае на рубеже XIX-XX веков. В Актуальные вопросы истории Сибири. Тринадиатые научные чтения памяти профессора А.П. Бородавкина: Сборник научных статей (cс. 204-209). АЗБУКА.

Лаппо, Г. (2001). Города Европейской России в конце XIX в. В Город и деревня в европейской России: Сто лет перемен. Монографический сборник (сс. 65-78). ОГИ.

Лысенко, Ю. А. (2019). Акторы социально-экономической модернизации центрально-азиатского региона Российской империи (вторая половина XIX - начало XX в.). В Центральная Азия на перекрестке европейских и азиатских политических интересов: XVIII-XIX вв.: Сборник научных трудов международного семинара (сс. 40-57). Онто-принт.

Макушев, А. Е. (2020). Метаморфозы промышленной статистики в обзорах губерний Среднего Поволжья в начале XX в. Экономическая история, 16(4), 388-398. https://doi.org/ 10.15507/2409-630X.051.016.202004.388-398

Миллер, А., \& Черный, Д. (Ред.). (2017). Города илперии в годы Великой войны и револющии: Сборник статей. Нестор-История.

Миронов, Б. Н. (2003). Социальная история России периода империи (XVIII - начало XX в.) (Т. 1). «Дмитрий Буланин».

Нефедова, Т., \& Трейвиш, А. (2001). Города как экономические центры: Вековая эволюция. В Город и деревня в европейской России: Сто лет перемен. Монографический сборник (сс. 95-123). ОГИ.

Обзор Акмолинской области ... [По годам]. (1871-1917). Государственная публичная историческая библиотека России. http://elib.shpl.ru/ru/nodes/45712

Обзор Закаспийской области ... [по годам]. (1892-1916). Государственная публичная историческая библиотека России. http://elib.shpl.ru/ru/nodes/46320

Обзор Самаркандской области ... [по годам]. (1891-1912). Государственная публичная историческая библиотека России. http://elib.shpl.ru/ru/nodes/46521

Обзор Семипалатинской области ... [по годам]. (1871-1913). Государственная публичная историческая библиотека России. http://elib.shpl.ru/ru/nodes/46327

Обзор Семиреченской области ... [по годам]. (1883-1915). Государственная публичная историческая библиотека России. http://elib.shpl.ru/ru/nodes/50512

Обзор Сыр-Даръинской области ... [по годам]. (1890-1916). Государственная публичная историческая библиотека России. http://elib.shpl.ru/ru/nodes/50528 
Обзор Тургайской области ... [по годам]. (1871-1916). Государственная публичная историческая библиотека России. http://elib.shpl.ru/ru/nodes/50764

Обзор Уральской области ... [по годам]. (1868-1916). Государственная публичная историческая библиотека России. http://elib.shpl.ru/ru/nodes/28162

Обзор Ферганской области ... [по годам]. (1889-1916). Государственная публичная историческая библиотека России. http://elib.shpl.ru/ru/nodes/50832

Положение об управлении Туркестанского края. (1903). Типо-Литография В.Н. Ильина.

Рыгалова, М. В. (2021). Обзоры областей Российской империи как источник по истории образования (на примере областей Степного края и Туркестана). Известия Алтайского государственного университета, 2, 66-70. https://doi.org/10.14258/izvasu(2021)2-10

Семенов, В. П. (Ред.). (1903). Россия. Полное географическое описание нашего отечества. Том 18. Киргизский край. Издание А. Ф. Девриена.

Статистический ежегодник России 1914 г. Год одиннадцатый. (1915). Петроград.

Фортунатов, А. Ф. (1906). Несколько данных о численности и составе населения России. Типография Ф. Я. Бурче.

Харсеева, О. В. (2017). Обзоры губерний как источник информации о состоянии преступности в России в XIX - начале XX вв. История, теория, практика российского права, 10, 125-137.

Хэ, Ч. (2011). Обзорный доклад о модернизащии в мире и Китае (2001-2010). Весь Мир.

Численность и состав рабочих в России на основании данных Первой всеобщей переписи населения Российской илперии 1897 г. (Т. 1). (1906). Санкт-Петербург.

\section{References}

Aleshin, P. N. (2019). Functioning of zemstvo veterinary service in Russia in the second half of the 19th - early 20th century (based on surveys of provinces). Current scientific thinking, 5, 54-61. (In Russian).

Bochkareva, I. B. (2020). Private capital in the process of railway construction in Turkestan (1970s - early 20th century). Izvestia of Altai State University, 5, 13-18. https://doi.org/ 10.14258/izvasu(2020)5-01 (In Russian).

Buktugutova, R. S. (2010). From the history of everyday life of the inhabitants of district towns in the Steppe region at the end of the 19th and beginning of the 20th centuries. Bulletin of Kazakh National Pedagogical University named after Abay. Series "Historical and Socio-Political Sciences", 2, 8-13. (In Russian).

Dzhanieva, R. M.(2007). Socio-economic and cultural development of the district towns in the Steppe region in the late 19th and early 20th centuries. [PhD thesis]. Omsk State Pedagogical University. (In Russian).

Eremin, A. A. (2021). Oblast Reviews as a Source for the Credit-Banking System in the Stepnoy Krai at the Turn of the 19th-20th Centuries. In Current Issues of Siberian History. Thirteenth Scientific Readings in Memory of Professor A.P. Borodavkin: Collection of Scientific Articles (pp. 204 209). AZBUKA. (In Russian).

Fortunatov, A. F. (1906). Some data on the size and composition of Russia's population. Printing house of F. J. Burche. (In Russian). 
He, Ch. (2011). Overview report on modernisation in the world and China (2001-2010). Vws Mir. (In Russian).

Kharseeva, O. V. (2017). The reviews of provinces as a source of information on the state of crime in Russia in the 19th and early 20th centuries. History, theory and practice of Russian law, 10, 125-137. (In Russian).

Lappo, G. (2001). Cities of European Russia in the late 19th century. In City and Village in European Russia: One Hundred Years of Change. A monographic collection (pp. 65-78). OGI. (In Russian).

Lysenko, Y. A. (2019). Actors of socio-economic modernisation of the Central Asian region of the Russian Empire (second half of the 19th century to the beginning of the 20th century). In Central Asia at the Crossroads of European and Asian Political Interests: 18th-19th Centuries: Proceedings of an International Seminar (pp. 40-57). Onto-print. (In Russian).

Makushev, A. E. (2020). Metamorphosis of industrial statistics in reviews of the provinces of the Middle Volga region in the early 20th century. Economic history, 16(4), 388-398. https://doi.org/ 10.15507/2409-630X.051.016.202004.388-398 (In Russian).

Miller, A., \& Cherny, D. (Eds.). (2017). Cities of the Empire during the Great War and Revolution: A Collection of Articles. Nestor-History. (In Russian).

Mironov, B. N. (2003). Social history of Russia in the imperial period (18th - early 20th century). (Vol. 1). "Dmitry Bulanin". (In Russian).

Nefedova, T., \& Treyvish, A. (2001). Cities as Economic Centres: A Century of Evolution. In City and Village in European Russia: One Hundred Years of Change. A monographic collection (pp. 95-123). OGI. (In Russian).

Number and composition of workers in Russia, based on data from the First General Population Census of the Russian Empire in 1897. (Vol. 1). (1906). Saint Petersburg. (In Russian).

Overview of Akmola Oblast ... [By year]. (1871-1917). State Public Historical Library of Russia. http://elib.shpl.ru/ru/nodes/45712 (In Russian).

Overview of the Ferghana region ... [by year]. (1889-1916). State Public Historical Library of Russia. http://elib.shpl.ru/ru/nodes/50832 (In Russian).

Overview of the Samarkand region ... [by year]. (1891-1912). State Public Historical Library of Russia. http://elib.shpl.ru/ru/nodes/46521 (In Russian).

Overview of the Semipalatinsk region ... [by year]. (1871-1913). State Public Historical Library of Russia. http://elib.shpl.ru/ru/nodes/46327 (In Russian).

Overview of the Semirechenskaya oblast ... [by year]. (1883-1915). State Public Historical Library of Russia. http://elib.shpl.ru/ru/nodes/50512 (In Russian).

Overview of the Syr Darya region ... [by year]. (1890-1916). State Public Historical Library of Russia. http://elib.shpl.ru/ru/nodes/50528 (In Russian).

Overview of the Trans-Caspian region ... [by year]. (1892-1916). State Public Historical Library of Russia. http://elib.shpl.ru/ru/nodes/46320 (In Russian).

Overview of the Turgai region ... [by year]. (1871-1916). State Public Historical Library of Russia. http://elib.shpl.ru/ru/nodes/50764 (In Russian).

Overview of the Ural Region ... [by year]. (1868-1916). State Public Historical Library of Russia. http://elib.shpl.ru/ru/nodes/28162 (In Russian). 
Regulations on the Turkestan Province Administration. (1903). V. N. Ilyin's Printing and Lithography. (In Russian).

Rygalova, M. V. (2021). Overviews of the Regions of the Russian Empire as a Source for the History of Education (Using the Regions of Stepnoy Krai and Turkestan as an Example). Izvestia of Altai State University, 2, 66-70. https://doi.org/10.14258/izvasu(2021)2-10(In Russian).

Semenov, V. P. (Ed.). (1903). Russia. A Complete Geographical Description of Our Fatherland. Vol. 18. Kirghiz territory. A. F. Devrien's edition. (In Russian).

Statistical Yearbook of Russia 1914. Year eleven. (1915). Petrograd. (In Russian).

Vlasova, A. I. (2020). Characteristics of the medical and sanitary service of Akmola region of the Stepnoy Krai in the 1970s - early XX century. (Based on statistical reviews of the region for 1870-1915). Izvestia of Altai State University, 3, 25-30.

https://doi.org/10.14258/izvasu(2020)3-03 (In Russian). 